\title{
Identifikasi Miskonsepsi Konsep Kimia Dan Upaya Mengatasinya Melalui Chemistry Clinic Bagi Pada Guru Anggota Mgmp Kimia
}

\section{Identify of Misconception in Chemistry as Efforts Retraining and Remediating Use Chemistry Clinic to Teacher Being Member of MGMP Chemistry in District of Sleman}

\author{
Isana Supiah YL, K.H. Sugiyarto dan Heru Pratomo Al.
}

Jurusan Pendidikan Kimia, FMIPA, UNY, *Email: isanasyl2000@yahoo.com

\begin{abstract}
Abstrak
Program pengabdian pada masyarakat (PPM) ini bertujuan untuk (1) mengidentifikasi miskonsepsi yang dialami guru pada materi kimia SMA yang berhubungan dengan kimia anorganik dan kimia fisik, dan (2) memberikan pendampingan untuk meningkatkan penguasaan materi sesuai modul guru pembelajar bagi anggota MGMP kimia Kabupaten Sleman.Kegiatan dilakukan selama 3 kali pertemuan. Pertemuan pertama di SMAN 1 Pakem, dihadiri 24 orang, membahas Sifat Koligatif Larutan dan menyusun Instrumen Penilaian. Pertemuan kedua di SMAN 2 Sleman, dihadiri 27 orang, membahas Penelitian Tindakan Kelas, Laju Reaksi, Termokimia, dan Elektrolisis. Pertemuan ketiga di SMAN 1 Seyegan, dihadiri 24 orang, membahas Teori Atom dan Ikatan Kimia. Kesimpulan daripada kegiatan ini, adalah (1) beberapa guru masih banyak mengalami miskonsepsi dalam pembahasan materi: Laju Reaksi, Termokimia, Elektrolisis, Sifat Koligatif Larutan, dan Bilangan Kuantum dan (2) Modul Guru Pembelajar yang perlu dipahami kembali oleh para guru anggota MGMP Kimia Kabupaten, adalah Modul A, D, G, dan J, baik dalam materi pedagogik maupun kimianya.
\end{abstract}

Kata kunci: miskonsepsi kimia, modul guru pembelajar.

\begin{abstract}
The community service program aims to (1) identify and indicate the presence of misconceptions in concept of inorganic and physical chemistry that happen of chemistry teachers members of MGMP in Sleman, and (2) give tutorial to understand the modul of core teachers.This activity was conducted in 3 session by face-to-face remediation. The first activity was held in SMAN 1 Pakem attended by 24 teachers, discussed Colligative Properties and Assessment. The second activity was held in SMAN 2 Sleman attended by 27 teachers, discussed Action Research, Rate of Reaction, Thermochemistry, and Electrolysis. And the last activity was held ini SMAN 1 Seyegan attended by 24 teachers, discussed Atomic Structure and Chemical Bonding. It can be concluded that (1) a few of the teachers are misconceptions on the concept of Rate of Reaction, Thermochemistry, Electrolysis, Colligative Properties, and Quantum number. (2) The modul of core teachers must be understood, especially the Modul A, D, G, and J..
\end{abstract}

Keywords: misconception in chemistry clinic, modul of core teachers

\section{PENDAHULUAN}

Pada suatu kesempatan, Heru Pratomo dan Sugiyarto (2013) menemukan bahwa sebagian guru anggota musyawarah guru mata pelajaran (MGMP) Kimia Kabupaten Bantul merasakan kesulitan dalam menjawab soal olimpiade kimia tingkat kabupaten, sehingga memerlukan pendampingan. Soal olimpiade kimia memang memiliki tingkat kesulitan di atas rata-rata bagi siswa SMA/MA, karena berisi soal setingkat perguruan tinggi. Situasi demikian ini patut diduga juga terjadi pada guru di kabupaten lain, sebab mereka sering berkomunikasi melalui forum MGMP dengan buku acuan yang sama.

Pada kesempatan lain, saat melaksanakan pengabdian masyarakat pada anggota MGMP Kimia Kabupaten Sleman, 
Heru Pratomo dan Sugiyarto (2014) menemukan bahwa: sebagian besar peserta (> 70\%) masih perlu meningkatkan penguasaan materi kimia anorganik, kimia organik dan kimia fisik untuk mendampingi siswa dalam menghadapi olimpiade kimia tingkat Kabupaten/Kota. Disamping itu peserta merasakan adanya hal-hal baru yang harus dikuasai untuk mendampingi siswa dalam menghadapi soal-soal olimpiade kimia tingkat SMA.

Guru harus mendampingi siswa di sekolah secara formal, sementara guru sendiri sering mengalami miskonsepsi. Sementara itu, berdasarkan temuan penelitian dan fakta yang dijumpai di lingkungan MGMP, nampaknya perlu pendalaman dan remidiasi terhadap miskonsepsi yang dialami para guru kimia SMA melalui forum MGMP. Pelaksanaan chemistry clinic (Heru Pratomo, dan Sugiyarto, 2013) di Kabupaten Bantul sangat diapresiasi oleh guru-guru anggota MGMP Kimia. Di samping itu, hasil test diagnostik menunjukkan bahwa sebagian besar peserta $(63,27 \%)$ mengalami miskonsepsi pada konsep kesetimbangan kimia, khususnya tentang pergeseran kesetimbangan (Heru Pratomo, Sugiyarto dan Isana, 2015: 16). Oleh karena itu masih perlu dilakukan pendampingan bagi guru untuk mengatasi miskonsepsi yang terjadi pada konsep kimia yang lain.

Guru-guru yang mengajar di SMA/MA setiap saat berkutat dengan pokok bahasan yang sama dalam pembelajaran kimia dari tahun ke tahun. Karena daya ingat seseorang yang sangat terbatas, ini pun terjadi pada guru, tidak tertutup kemungkinan guru sangat menguasai materi pelajaran kimia kelas XI IPA tetapi kurang menguasai materi pembelajaran kelas XII IPA, bahkan kelas X. Padahal sesungguhnya hal demikian tidak boleh terjadi, karena ini sangat berpengaruh dan akan nampak pada saat dilakukan UKG. Hasil UKG guru kimia yang mengajar di SMK lebih rendah jika dibandingkan dengan guru kimia yang mengajar di SMA/MA.
Menurut laporan ketua MGMP Kimia Kabupaten Sleman, lebih dari $60 \%$ anggotanya belum lulus uji kompetensi guru (UKG) pada Juni 2016. Beberapa materi UKG perlu mendapatkan penyegaran kembali, baik materi kimia maupun materi pedagogiknya. Kegiatan ini dilaksanakan bekerjasama dengan kegiatan MGMP Kimia Kabupaten Sleman, dan model pendampingannya dilaksanakan dengan program chemistry clinic. Hal ini perlu dilaksanakan, karena merupakan sarana yang tepat untuk penyegaran sekaligus meningkatkan pengetahuan bagi guru kimia di SMA/MA, khususnya di Kabupaten Sleman.

Van den Berg (1991) menegaskan bahwa dalam bidang ilmu pengetahuan alam (IPA), miskonsepsi umumnya identik dengan kesalahan. Jadi, istilah miskonsepsi diartikan sebagai konsep apa saja yang berbeda dari pemahaman ilmiah yang umumnya diterima untuk konsep yang bersangkutan. Sekali miskonsepsi ini terintegrasi ke dalam struktur kognitif siswa, akan berpengaruh pada materi pembelajaran selanjutnya. Hal ini terjadi karena informasi baru yang masuk ke dalam struktur kognitif tidak terkoneksi secara tepat, sehingga terjadilah pemahaman yang lemah atau pemahaman-salah (misunderstanding) terhadap konsep yang bersangkutan.

Namun demikian, Novak dan Gowin (1986) berpendapat bahwa makna yang terungkap bukanlah suatu miskonsepsi pada siswa, melainkan pada makna fungsional. Hal ini didukung oleh kenyataan bahwa miskonsepsi dapat berlangsung dalam kurun waktu cukup lama, namun jika konsepkonsep penghubung berhasil diintegrasikan ke dalam kerangka konseptual seseorang, ternyata miskonsepsi yang semula terjadi dapat direduksi bahkan dihilangkan.

Kesulitan dalam memahami konsep sains, termasuk kimia, hingga mengakibatkan terjadinya miskonsepsi, barangkali sangat bergantung pada karakteristik konsep itu sendiri dan juga kultur (maha)siswa. Berdasarkan teori konstruktivistik, ilmu pengetahuan dibangun 
dalam pikiran (maha)siswa, sedangkan pembentukan konsep dalam pikiran ini dipengaruhi oleh pre-konsep yang ada sebelumnya (Bodner: 1986). Dengan demikian kekeliruan pembentukan konsep yang ditransfer dapat saja menghasilkan konsep yang berbeda (bahkan "salah") dari kebenaran konsep yang diharapkan, sehingga miskonsepsi menjadi hal yang sangat mungkin terjadi.

Guru-guru yang mengajar di SMA/MA setiap saat berkutat dengan pokok bahasan yang sama dalam pembelajaran kimia dari tahun ke tahun. Karena daya ingat seseorang yang sangat terbatas, ini pun terjadi pada guru, tidak tertutup kemungkinan guru sangat menguasai materi pelajaran kimia kelas XI IPA tetapi kurang menguasai materi pembelajaran kelas XII IPA, bahkan kelas X. Padahal sesungguhnya hal demikian tidak boleh terjadi, karena ini sangat berpengaruh dan akan nampak pada saat dilakukan uji kompetensi guru (UKG).

\section{SOLUSI/TEKNOLOGI}

\section{Khalayak Sasaran}

Sasaran kegiatan PPM adalah para guru SMA anggota MGMP Kimia di Kabupaten Sleman, sebanyak 40 orang

2. Metode Kegiatan

Kegiatan dilaksanakan dengan metode remidiasi tatap-muka. Sebelum dilakukan pendampingan, ketua MGMP menyampaikan kepada tim pengabdian tentang adanya modul guru pembelajar. Ada beberapa modul guru pembelajar yang tingkat kelulusan UKG nya rendah. Kegiatan ini difokuskan pada modul yang tingkat kelulusan rendah tersebut. Kegiatan dilaksanakan dengan membahas modul, menganalisis soal latihan pada modul, serta memberikan materi pengayaan sesuai modul yang di bahas.

\section{HASIL DAN DISKUSI}

Kegiatan ini dapat terlaksana berkat kerjasama yang baik dengan pengurus MGMP Kimia dan Dinas Pendidikan Kabupaten Sleman. Kegiatan guru pembelajar yang dilaksanakan pada 10 September 2016 di SMAN 1 Kalasan, dibuka oleh Kepala Dinas Pendidikan Kabupaten Sleman. Dalam sambutannya Kepala Dinas menekankan pentingnya Guru Pembelajar dan menyarankan adanya kerjasama dengan perguruan tinggi. Arahan ini ditanggapi oleh Ketua MGMP yang sebelumnya sudah berkoordinasi dengan tim PPM ini, dan jadilah kegiatan PPM ini mendukung pelaksanaan kegiatan guru pembelajar kimia di Kabupaten Sleman.

Kegiatan pertama dilaksanakan di SMAN 1 Pakem, dikuti oleh 24 orang membahas Modul G tentang Sifat Koligatif Larutan (sesi pertama) dan Instrumen Penilaian (sesi kedua)

Banyak anggota MGMP Sleman yang belum lulus Modul G, karena materi modul ini adalah materi kelas XII IPA. Mereka beralasan kegagalan mereka karena kebanyakan dari mereka tidak mengajar kelas XII. Kejadian ini perlu dikritisi, bahwa sebaiknya guru tidak hanya menguasai materi pelajaran kimia sesuai kelas yang diampunya, tetapi guru harus menguasai materi kimia kelas X sd XII.

Sebenarnya Sifat Koligatif Larutan bukanlah materi yang pelik, namun dengan soal berpikir tingkat tinggi ternyata materi ini cukup membuat guru kewalahan dalam mengerjakan soal. Sebagian dari mereka tidak dapat memberikan contoh materi ini dalam kehidupan sehari-hari, dan merancang percobaan yang dilakukan siswa. Sebagian lain salah konsep pada syaratsyarat berlakunya hukum Raoult.

Para guru juga banyak mengalami kesulitan dalam menyusun instrumen penilaian pada taraf berpikir tingkat tinggi. Oleh karena itu pada kesempatan ini juga diberikan contoh soal dalam taraf berpikir tingkat tinggi. Selama ini guru merasa kesulitan memandu siswa untuk menjawab pertanyaan secara runtut, karena mereka terbiasa dengan jawaban untuk soal pilihan ganda.

Pelaksanaan pendampingan pada pertemuan pertama ini berhasil memacu semangat guru dan memotivasi mereka 
untuk belajar menghadapi UKG mendatang. Mereka berharap pada pertemuan selanjutnya juga dapat memberikan wawasan baru dan memotivasi mereka.

Kegiatan kedua dilaksanakan di SMAN 2 Sleman dihadiri oleh 27 orang, membahas Modul $\mathrm{J}$ tentang Penelitian Tindakan Kelas (PTK) dan Modul D tentang Redoks, Termokimia, dan Laju Reaksi.

Pembahasan PTK secara umum dimaksudkan untuk menumbuhkan semangat para guru untuk melakukan penelitian tindakan kelas, demi meningkatkan proses pembelajaran secara umum. Penelitian tindakan secara umum dilakukan untuk memperbaiki proses yang sedang berlangsung serta penelitian kualitatif untuk menggali informasi secara rinci dan lengkap. Pada kegiatan ini terungkap bahwa para guru merasa kesulitan dalam menyusun instrumen penelitian.

Pembahasan materi Redoks, Termokimia dan Laju Reaksi terutama ditujukan untuk membahas bagian-bagian yang oleh siswa kurang dipahami, dengan memberikan alternatif cara penyampaian kepada siswa agar siswa tidak menanggapi materi kimia secara "sastra" tetapi secara sain, artinya perlu dikembangkan "logika" untuk mensikapi materi kimia bukan dengan cara dihafalkan. Materi Redoks yang diulas antara lain "Penentuan Bilangan/Tingkat Oksidasi”, yang selama ini diberikan catatan panjang lebar sehingga para siswa dituntut untuk menghafalkan supaya bisa menentukan bilangan oksidasi unsur dalam senyawa, ternyata kalau dilakukan dengan "logika" menjadi lebih sederhana dengan tanpa menghafalkan kata-kata yang panjang lebar, sehingga para siswa "tidak terbebani" belajar kimia tetapi menjadi makin tertarik untuk mempelajari kimia. Demikian juga mempelajari "Elektrolisis", bila disikapi dengan "logika" akan menjadi mudah dan sederhana, sehingga para siswa menjadi makin menikmati belajar kimia.

Cara yang sama juga dapat diterapkan untuk materi Termokimia dan Laju Reaksi. Pada materi Termokimia seringkali para siswa kurang dapat memahami konsep reaksi endotermik dan eksotermik bila disajikan dengan gambar, perubahan entalpi dan kalor netralisasi. Pada materi Laju Reaksi, konsep laju reaksi secara umum masih kurang dipahami para siswa, demikian juga pemahaman faktor-faktor yang berpengaruh terhadap laju reaksi.

Kegiatan ketiga dilaksanakan di SMAN 1 Seyegan dihadiri oleh 23 orang, membahas Modul A, tentang Struktur Atom dan Ikatan Kimia.

Banyak miskonsepsi dialami oleh guru dalam penulisan konfigurasi elektron, menentukan bilangan kuantum dan membedakan bilangan oksidasi dengan muatan formal. Materi dalam modul guru pembelajar (Modul A) sebenarnya juga banyak mengalami kesalahan konsep, dan itu biasa dijumpai guru dalam pembelajaran di kelas. Melalui kegiatan ini telah disegarkan kembali pemahaman guru terhadap materi yang terdapat dalam Modul A.

Dalam setiap sesi kegiatan disertai dengan tanya jawab atau diskusi yang suasananya sangat hidup. Para peserta sangat antusias menanggapi materi yang disampaikan, dan timbul pertanyaan yang bermacam-macam, bahkan kadang-kadang muncul pertanyaan di luar topik yang dibicarakan. Ini menunjukkan bahwa kegiatan ini sangat dibutuhkan para peserta, atau dengan kata lain para peserta banyak mendapatkan penyegaran atau tambahan pengetahuan/ pengayaan melalui kegiatan ini. Menurut tanggapan peserta, materi yang disampaikan semuanya dirasakan bermanfaat, dan disampaikan dengan baik sehingga memuaskan para peserta.

Secara lengkap, masukan dari para peserta terangkum di bawah ini :

1. Kegiatan sangat diperlukan, sebab masih banyak peserta yang mengalami kesulitan dalam memahami materi dalam modul guru pembelajaran.

2. Masih perlu kegiatan lanjutan, khususnya penyusunan proposal PTK, instrument penilaian, dan materi kimia terkini. 
3. Diperlukan sebagai pengayaan dan penyegaran bagi guru yang kebetulan tidak mengajarkan modul yang dibahas.

4. Waktu yang diperlukan masih kurang banyak, sehingga belum mendalam.

\section{KESIMPULAN}

1. Beberapa guru masih banyak mengalami miskonsepsi dalam pembahasan materi: Laju Reaksi, Termokimia, Elektrolisis, Sifat Koligatif Larutan, dan Bilangan Kuantum.

2. Modul Guru Pembelajar yang perlu dipahami kembali oleh para guru anggota MGMP Kimia Kabupaten, adalah Modul A, D, G, dan J, baik dalam materi pedagogik maupun kimianya.

\section{UCAPAN TERIMA KASIH}

Pelaksana PPM mengucapkan terimakasih kepada FMIPA UNY yang telah membiayai penelitian ini melalui anggaran DIPA BLU Universitas Negeri Yogyakarta Tahun 2016.

\section{PUSTAKA}

Bodner, G.M. 1986 "Contrustructivism : A Theory of Knowledge", Journal of Chemical Education, 63, 873878.

Euwe van den Berg (Ed). 1991. Miskonsepsi Fisika dan Remidiasi. Salatiga: UKSW

Heru Pratomo Al. 2013. Pendampingan guru anggota MGMP Kabupaten Sleman dalam memecahkan soal olimpiade kimia tingkat kabupaten. (Makalah).

Heru Pratomo Al., dan K.H. Sugiyarto. 2013. Laporan PPM: "Chemistry clinic" sebagai upaya penyegaran dan remediasi guru anggota
MGMP kimia Kabupaten Bantul. Yogyakarta: FMIPA UNY.

Heru Pratomo Al., dan K.H. Sugiyarto. 2014. Laporan PPM: Pendampingan guru anggota MGMP Kimia Kabupaten Sleman dalam menyiapkan siswa untuk menghadapi olimpiade kimia tingkat Kabupaten/Kota. Yogyakarta: FMIPA UNY

Heru Pratomo Al., K.H. Sugiyarto. dan Isana Supiah YL. 2016. Laporan PPM: Pendampingan pembina olimpiade kimia siswa melalui chemistry clinic bagi guru anggota MGMP Kimia Kabupaten Bantul. Yogyakarta: FMIPA UNY

Kristian H, Sugiyarto. 2009. Laporan Kegiatan Pendampingan bagi Guru Pembina Olimpiade. Yogyakarta: FMIPA UNY.

Kristian H, Sugiyarto, Heru Pratomo Al, dan Togu Gultom, 2010. Laporan Penelitian: Miskonsepsi atas Pokok Bahasan Bilangan Kuantum dan Konfigurasi Elektronik pada Berbagai BukuAjar Kimia SMA dan Para Guru Penggunanya. Yogyakarta: FMIPA UNY.

Kristian H, Sugiyarto, dan Heru Pratomo Al. 2013. Laporan Penelitian: Miskonsepsi atas Pokok Bahasan Kesetimbangan Kimia dan Reaksi Redoks pada Berbagai Buku-Ajar Kimia SMA dan Para Guru Penggunanya. Yogyakarta: FMIPA UNY.

Novak, J. D., and Godwin, D. B., 1986. Learning How to Learn, Cambridge: Cambridge University Press.

Sediono Abdullah (ed). 2016. Modul Guru Pembelajar. Bandung: PPPPTK IPA, Dirjen Guru dan Tenaga Kependidikan Kemendikbud. 